Full length article

\title{
Chronic hyperosmotic stress interferes with immune homeostasis in striped catfish (Pangasianodon hypophthalmus, S.) and leads to excessive inflammatory response during bacterial infection
}

\author{
Mélodie Schmitz a, *, Jessica Douxfils ${ }^{a}$, Syaghalirwa N.M. Mandiki a, Cédric Morana ${ }^{\text {b, }}$ \\ Sébastien Baekelandt ${ }^{\mathrm{a}}$, Patrick Kestemont ${ }^{\mathrm{a}}$ \\ ${ }^{\text {a } U n i v e r s i t y ~ o f ~ N a m u r, ~ R e s e a r c h ~ U n i t ~ i n ~ E n v i r o n m e n t a l ~ a n d ~ E v o l u t i o n a r y ~ B i o l o g y, ~ N a m u r, ~ B e l g i u m ~}$ \\ ${ }^{\mathrm{b}}$ Katholieke Universiteit Leuven, Department of Earth and Environmental Sciences, Leuven, Belgium
}

\section{A R T I C L E I N F O}

\section{Article history:}

Received 23 March 2016

Received in revised form

11 June 2016

Accepted 22 June 2016

Available online 24 June 2016

\section{Keywords:}

Hyperosmotic stress

Striped catfish

Osmolality

Immunity

\begin{abstract}
A B S T R A C T
Hyperosmotic stress has often been investigated from osmoregulation perspectives while the effects of such stress on the immune capacity remain largely unexplored. In this study, striped catfish were submitted to three salinity profiles (freshwater, low saline water, saline water) during 20 days, followed by infection with a virulent bacteria, Edwardsiella ictaluri, responsible for the enteric septicaemia of catfish. Osmoregulatory (plasma osmolality, gill $\mathrm{Na}^{+} \mathrm{K}^{+}$ATPase), immune (blood cells, lysozyme activity, complement activity, respiratory burst) parameters and mortality rate were investigated. In addition, abundances of heat shock protein 70 and high mobility group box 1 were explored. With elevated salinity, plasma osmolality severely increased while gill $\mathrm{Na}^{+} \mathrm{K}^{+}$ATPase slightly increased. Salinity alone stimulated the number of granulocytes, lysozyme activity and respiratory burst but depleted the number of thrombocytes. Salinity in combination with infection stimulated the number of monocytes and ACH50. On the contrary, erythrocytes, hematocrit, heat shock protein 70 and high mobility group box 1 did not significantly vary with salinity profiles. Then, salinity induced earlier onset on mortalities after E. ictaluri inoculation whereas cumulative mortality reach $79.2 \%, 67.0 \%$ and $91.7 \%$ respectively in freshwater, low saline water and saline water. In conclusion, salinity stimulates several immune functions in striped catfish but prolonged exposure to excessive hyperosmotic condition may lead to excessive inflammatory response and death.
\end{abstract}

() 2016 Elsevier Ltd. All rights reserved.

\section{Introduction}

The striped catfish (Pangasianodon hypophthalmus, Sauvage) is a potamodromous catfish endemic of the Mekong River Basin and the Chao Praya River in Thailand. Nowadays, striped catfish farms are the major inland aquaculture production in Southeast Asia. In 2014, worldwide striped catfish production reached 1.2 million of tons, which represent almost 1.7 billion US\$ in the international trade [1]. Vietnam is by far the largest striped catfish producer,

Abbreviations: HSP, Heat shock proteins; HMGB1, High-mobility group protein B1; DAMPS, Damage-associated molecular patterns; LD5096, Lethal dose $50 \% 96 \mathrm{~h}$; HBSS, Hank's Balanced Salt Solution; RRBC, Rabbit red blood cells; ACH50, Alternative complement hydrolysis 50\%; ESC, Enteric septicaemia of catfish.

* Corresponding author. Research Unit in Environmental and Evolutionary Biology, University of Namur, rue de Bruxelles 61, B-5000 Namur, Belgium.

E-mail address: melodie.schmitz@unamur.be (M. Schmitz). exporting striped catfish to more than 80 countries, mainly in the European Union and United States [1]. In Vietnam, the Mekong Delta accounts for more than $75 \%$ of the Vietnamese production with a total farming area of 5509 ha in 2011 [2]. Nevertheless, striped catfish industry in the Mekong Delta is currently facing many climatic challenges, particularly extensive salinity intrusion induced by the global climate changes. According to 4 RCP (representative concentrations pathways), ocean thermal expansion (30-55\%) and glaciers melting (15-35\%) will induce a global sea level rise comprised between 0.26 and $0.98 \mathrm{~m}$ by 2100 . In the Mekong Delta, in 2016, saline water intrusions have already been observed up to $90 \mathrm{~km}$ far from the River Mouth, thereby rising salinity level up to $12 \mathrm{ppt}$ in many aquacultural provinces [3]. The latter study also suggested that such salinity conditions may affect catfish hematological and immune status [unpublished data].

Environmental salinity is an important parameter for aquatic organisms. Modification of salinity may be responsible for 
important biochemical and physiological troubles [4]. Studies evaluating fish acclimation from hyposmotic to hyperosmotic environment (relative to plasma) have been mainly looking at changes in the osmoregulatory system while the effects of such stressors on the immune capacity remain largely unexplored. Gilthead seabream (Sparus aurata) acclimated to low saline water (6 ppt) showed lower peroxidase and alternative complement activity in plasma compared to fish acclimated to brackish (12 ppt) and saline water (38 ppt) [4]. In Mozambique tilapia (Oreochromis mossambicus), renal and plasma lysozyme activities increased $1 \mathrm{~h}$ and $24 \mathrm{~h}$ after transfer from freshwater to saline water (25 ppt) while respiratory burst increased in spleen and kidney as early as $8 \mathrm{~h}$ post transfer [5]. In rainbow trout (Oncorhynchus mykiss), 3days acclimation to hyperosmotic water (12 and $29 \mathrm{ppt}$ ) resulted in elevated plasma lysozyme activity [6]. Hypo- or hyperosmotic shocks in grouper fry (Epinephelus sp.) induced higher susceptibility to infectious pancreatic necrosis virus [7]. Regarding adaptative immune function, a study on fish vaccination revealed that barramundi (Lates calcarifier) acclimated to seawater produced a higher adaptative mucosal antibody response than barramundi acclimated to freshwater [8].

In eukaryotes, Heat Shock Proteins (HSP) and High-Mobility Group B1 (HMGB1) are constitutive and highly conserved molecular chaperones for DNA and proteins [9-11]. During cellular stress, HSPs and HMGB1 may be produced and released either actively or passively in the extracellular environment, in order to inhibit protein aggregation and to repair denatured proteins [12-14]. For immune defence, HMGB1 and HSPs (particularly HSP70 and 90) have key role in inflammation as well as in innate and adaptative immune function during bacterial or viral infection [10,15]. In the extracellular environment, they act as damage-associated molecular patterns (DAMPs) and affect many aspects of the immune response, particularly through activation of cell surface innate immune receptor, typically Toll like Receptor [16]. In fish, upregulation of HSP70 has been documented during biotic (i.e. infectious disease) and abiotic (e.g. osmotic, acidosis, heat, anoxia, toxins, protein degradation) stressors [10]. On the other hand, reports on HMGB1 are still limited and regulation of HMGB1 level by abiotic factors remains largely unknown. In red drum (Sciaenops ocellatus) and goldfish (Carassius auratus), bacterial infection elevated the abundance of HMGB1 transcript and protein from 12 to $48 \mathrm{~h}$ post challenge [17,18].

Following sterile or microbial injury, inflammatory processes are essential for tissue and wound repair. However, prolonged exposure to the detrimental agents and continuous release of DAMPs (e.g. typically HSPs, HMGB1, S100 calcium-binding proteins and purine metabolites) may lead to excessive inflammation and severe immunopathological conditions that may end up with tissue damage and death [19].

Understanding how salinity changes impact fish health and disease resistance is of critical importance, particularly for high commercial species such as the striped catfish. In the present study, we aimed to characterize the effects of hyperosmotic stressor on passive and induced innate immune defences of striped catfish. We hypothesized that prolonged exposure to hyperosmotic conditions (10 and $20 \mathrm{ppt}$ ) might unbalance the immune homeostasis of healthy fish by inducing chronic inflammation. Key factors of the osmoregulatory, inflammatory and immune components have been analysed at different time points during salinity exposure and compared to values obtained under freshwater conditions. Then, we further hypothesized that chronic inflammation may result in an excessive inflammatory response following microbial challenge, leading to serious diseases status and death. To verify this hypothesis, fish were challenged with a virulent strain of Edwardsiella ictaluri, responsible for ESC (enteric septicaemia of catfish) disease
[20]. Key parameters of the innate immune response, molecular chaperones (i.e. HSP 70 and HMGB1 protein) and cumulative mortality were compared between freshwater-held fish and salinity-challenged fish prior and after inoculation of the bacteria.

\section{Methods}

\subsection{Fish and in vivo stress experiment}

Investigations have been conducted according to the guidelines for animal use and care in compliance with Belgian and European regulation on animal welfare (ethical protocol $n^{\circ} \mathrm{KE} 12 / 189$ ). One week-old striped catfish (Pangasianodon hypophthalmus, Sauvage) were provided by the Nam Sai catfish farm (Ban Sang, Thailand). Juveniles were maintained in fish facilities in the University of Namur (Belgium) at $28{ }^{\circ} \mathrm{C}$ under constant aeration and photoperiod (12L:12D) in recirculating aquaculture systems. Fish were daily fed ad libitum with commercial dry pellets (Troco Supreme $4.5 \mathrm{~mm}$, Coppens, The Netherlands). After 3 months, fish (40-50 g) were equally divided into 3 experimental groups each including four $100 \mathrm{~L}$ tanks (30 fish/tank). Fish were acclimated to their new housing conditions during 10 days. The first group of fish was maintained in freshwater $(0.4 \mathrm{ppt})$ during all the experiment. The second group of fish was exposed to low salinity water stressor namely to a gradual water salinity increase of $0.5 \mathrm{ppt}$ per day during 20 days $(0.4-10 \mathrm{ppt})$. The third group of fish was exposed to a higher saline stressor namely to a gradual salinity increase of $1 \mathrm{ppt}$ per day during 20 days (0.4-20 ppt). Salinity was increased by adding marine salt (Ocean Fish, Prodac, Italy) mixed with tap water until day 20 and then remained stable during the following bacterial challenge. On day 20, fish were anaesthetized in tricaine methanesulfonate MS-222 $\left(150 \mathrm{mg} \mathrm{L}^{-1}\right)$ and intraperitoneally injected with $0.025 \mathrm{ml} \mathrm{g}^{-1}$ fish of a bacterial solution ( $10^{6}$ bacteria $\mathrm{ml}^{-1}$ (LD50 $96 \mathrm{~h}$ ) of Hank's Balanced Salt Solution (HBSS, Sigma-Aldrich)). Mortality was daily recorded during 10 days. Fish (6 fish/tank) were sampled at the following time points: days $0,10,20$ and 23 . On the sampling days, fish were randomly collected in the tanks with nets and anaesthetized in MS-222 (Sigma-Aldrich) $\left(150 \mathrm{mg} \mathrm{L}^{-1}\right)$. Blood was collected by caudal vein puncture using a sterile $1 \mathrm{ml}$ heparinized syringe within 5 min and euthanized by cervical dislocation. Blood was kept on ice until plasma was separated by centrifugation at $4{ }^{\circ} \mathrm{C}(7000 \mathrm{~g}$, $10 \mathrm{~min}$ ) and frozen at $-80{ }^{\circ} \mathrm{C}$ pending analyses. The whole kidney was rapidly collected by gentle scratching with tweezers along the vertebral column and immediately frozen in liquid nitrogen. Gill filaments from left arches 1-2 were taken out and immediately frozen in liquid nitrogen. Spleen was stored on ice in L-15 media until respiratory burst assay was carried out the same day. Physicochemical data were measured daily in the outlet pipe using a multiparameter probe (WTW, Multi 350i): $\mathrm{O}_{2}: 5.7 \pm 0.5 \mathrm{mg} \mathrm{L}^{-1}$; $\mathrm{pH}: \quad 8.4 \pm 0.24$; temperature: $28.2 \pm 0.1{ }^{\circ} \mathrm{C}, \quad \mathrm{N}-\mathrm{NO}_{3}^{-}$: $3.55 \pm 2.27 \mathrm{mg} \mathrm{L}^{-1} ; \mathrm{N}-\mathrm{NO}_{2}^{-}: 0.019 \pm 0.005 \mathrm{mg} \mathrm{L}^{-1} ; \mathrm{N}-\mathrm{NH}_{3}^{+}$: $0.19 \pm 0.25 \mathrm{mg} \mathrm{L}^{-1}$. Measured salinities were closed to the expected values $( \pm 0.3 \mathrm{ppt})$ (Fig. 1$)$. The feed intake was measured daily.

\subsection{Bacterial challenge}

\subsubsection{Culture of the bacterial strain}

Virulent strain of E. ictaluri (TNA 015) was cultured on BHI (Brain Heart Infusion) agar (Sigma-Aldrich) at pH 7.4 and $28^{\circ} \mathrm{C}$. Small round and transparent colonies appeared after $48 \mathrm{~h}$ of incubation. Colonies were checked for specific shape and Gram staining under light microscopy. 


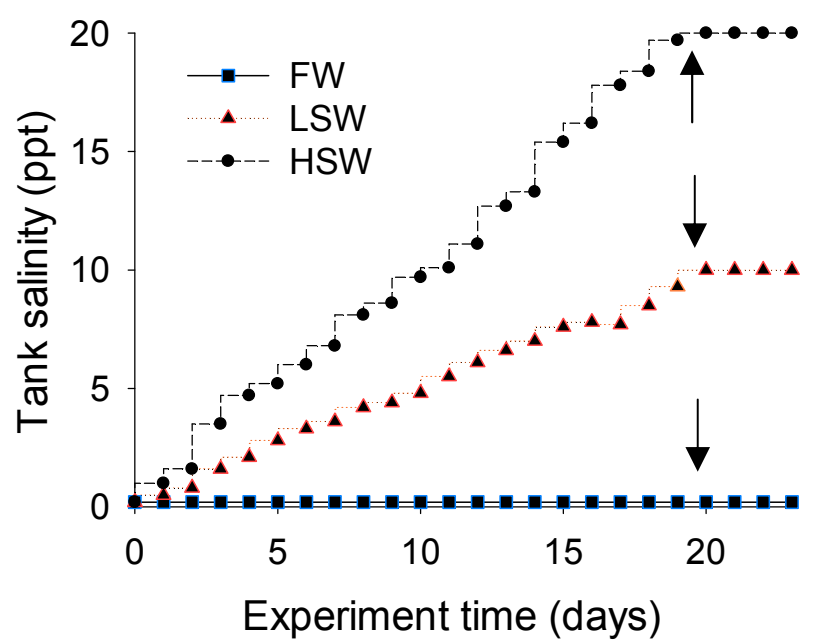

Fig. 1. Striped catfish salinity experiment regimens. Striped catfish were exposed (or not) to increasing salinity during 20 days in three independent recirculating systems. FW: Freshwater; LSW: Low saline water $(0-10 \mathrm{ppt})$; SW: saline water $(0-20 \mathrm{ppt})$. The arrows represent bacteria inoculation at day 20 .

\subsubsection{Bacteria count}

Bacteria were first numbered in a reference bacteria solution with optical density of 0.1 at $590 \mathrm{~nm}$. Serial exponential dilutions (100 to $10^{10}$ ) of $100 \mu \mathrm{l}$ of this reference bacteria solution were cultured in BHI agar during $48 \mathrm{~h}$ at $28{ }^{\circ} \mathrm{C}$ and the colonies were counted. A method of confirmation using DNA fluorochrome $4^{\prime}-6^{\prime}-$ diamidino-2-phenylindole (DAPI) was used. Serial exponential dilutions $\left(10^{4}\right.$ à $\left.10^{8}\right)$ were incubated $1 \mathrm{~h}$ in DAPI, filtered and counted on black filters under fluorescent microscopy. Based on these bacteria counts, it has been estimated that a reference E. ictaluri solution of optical density 0.1 cultured in BHI contained approximately $10^{9}$ bacteria $\mathrm{ml}^{-1}$ solution.

\subsubsection{Lethal dose 50\% (LD 50) $96 \mathrm{~h}$}

In a preliminary experiment, exponential doses of bacteria suspended in HBSS were injected to fish using an inoculation volume of $0.025 \mathrm{ml} \mathrm{g}^{-1}$ fish ( 4 tanks, $n=6$ per tank) in order to estimate the LD 5096h. The results indicated that an injection of $0.025 \mathrm{ml} \mathrm{g}^{-1}$ fish of a bacterial solution containing $10^{6} \mathrm{CFU} \mathrm{ml}{ }^{-1}$ induced 50\% mortality after $96 \mathrm{~h}$.

\subsubsection{Confirmation of infection}

Using API and Biolog biochemical identification systems, infection was confirmed (100\% probability for E. ictaluri) by the CER group (Belgian reference laboratory for animal health, Centre d'Economie Rurale-CER, Aye, Belgium), a laboratory specialized in screening and diagnosis of fish viral, bacterial and parasitic pathologies.

\subsection{Osmoregulatory parameters}

\subsubsection{Gill $\mathrm{Na}^{+} \mathrm{K}^{+}$ATPase activity}

Gill lysates were obtained by homogenizing (1:5) tissue in ice cold SEI buffer (Sucrose $0.25 \mathrm{M}$, EDTA $1 \mathrm{mM}$, Imidazole $50 \mathrm{mM}$ - pH 7.4) containing a protease inhibitor cocktail (Sigma) for $2 \times 30 \mathrm{~s}$ using a sterile potter homogenizer. Main debris were removed by 2 successive centrifugations at $10000 \mathrm{~g}$ during $5 \mathrm{~min}$ at $4{ }^{\circ} \mathrm{C}$. An aliquot $(50 \mu \mathrm{l})$ was used to measure the $\mathrm{Na}^{+} \mathrm{K}^{+}$ATPase activity according to the method of Mc Cormick (1995) [21]. One unit of $\mathrm{Na}^{+} \mathrm{K}^{+}$ATPase activity represents the consumption of $1 \mu$ mole $\mathrm{NADH} \mathrm{min}^{-1} \mathrm{ml}^{-1}$. Analyses were performed in duplicates.

\subsubsection{Plasma osmolality}

Plasma osmolality $(100 \mu \mathrm{l})$ was measured with a microosmometer (Type 6, Löser Messtechnik, Germany) in duplicates according to the depression of freezing point compared to pure water.

\subsection{Hematology}

\subsubsection{Blood cell populations}

Blood cells populations were analysed by flow cytometry (Flow Activated Cell Sorter Calibur, Flow Cytometry System) according to Inoue et al. (2002) [22a] (Fig. 2). Briefly, $10 \mu \mathrm{l}$ of fresh heparinized blood were mixed with $1950 \mu \mathrm{l}$ of HBSS and $40 \mu \mathrm{l}$ of fluorochrome DiOC $_{6}$ (3,3-dihexyloxacarbocyanine, Sigma-Aldrich, Germany) diluted 1:10 in ethanol. The tube was mixed gently and incubated at RT (room temperature) during $10 \mathrm{~min}$. The FACS was calibrated with TrueCount Beads diluted in HBSS. Each blood cell population was identified by its typical location in a FL-1 v. SSC and FSC v. SSC according to Inoue et al. (2002) [22a] and Pierrard et al. (2012) [22b] (Fig. 2). Five clusters were identified including erythrocytes, thrombocytes and lymphocytes, monocytes, eosinophils and heterophils. In order to validate this method, differential blood counts were previously done in 20 fish in light microscopy. Regarding to erythrocytes, blood was diluted $200 \times$ in HBSS and erythrocytes were counted on Neubauer hemocytometer. Regarding to leukocytes, subpopulations were differentially counted on blood smear staining with May Grunwald Giemsa according to Vazquez et al. (2007) [23]. Fig. 3 shows blood cell populations identified in light microscopy (Fig. 3). Flow cytometer analyses were in agreement with microscopic counts.

\subsubsection{Hematocrit}

Fresh heparinized blood was centrifuged in microhematocrit tubes at $10000 \mathrm{~g}$ during $5 \mathrm{~min}$ at RT.

\subsection{Immune parameters}

\subsubsection{Plasma lysozyme assay}

The lysozyme activity protocol was adapted from Ellis et al. (1990) [24]. Briefly, lysozyme activity assay was initiated by mixing $10 \mu \mathrm{l}$ of kidney homogenate or $10 \mu \mathrm{l}$ of plasma with $250 \mu \mathrm{l}$ of lyophilized Micrococcus lysodeikticus (Sigma) suspension (0.6 mg ml$~^{-1}$ in phosphate buffer at $\mathrm{pH} 6.2$ ). The difference in absorbance at $450 \mathrm{~nm}$ was monitored between $0 \mathrm{~min}$ and $15 \mathrm{~min}$ (linearity range). One unit of lysozyme activity represents the amount of lysozyme causing a 0.001 decrease in absorbance per minute. Samples were measured in duplicates.

\subsubsection{Plasma alternative complement pathway}

The alternative complement pathway was assayed in duplicates according to Sunyer and Tort (1995) [25]. Briefly, $10 \mu$ of rabbit red blood cells suspension (RRBC, Biomerieux) suspended at $3 \%$ in veronal buffer (Biomerieux) were mixed with serial dilutions of plasma. After incubation for $2 \mathrm{~h}$ at $28{ }^{\circ} \mathrm{C}$, the samples were centrifuged $\left(2000 \mathrm{~g}, 5 \mathrm{~min}, 4^{\circ} \mathrm{C}\right)$. A positive control sample $(100 \%$ haemolysis) was obtained by adding $60 \mu \mathrm{l}$ of distillate water to $10 \mu \mathrm{l}$ of RRBC. A negative control sample was obtained by adding $60 \mu \mathrm{l}$ of veronal buffer to $10 \mu \mathrm{l}$ of RRBC. The absorbance of supernatant was measured at $405 \mathrm{~nm}$. The ACH 50 value is defined as the reciprocal of the plasma dilution which induces $50 \%$ haemolysis of RRBC.

\subsubsection{Spleen respiratory burst}

Spleen respiratory burst was adapted from Rook et al. (1985) [26]. Using the back of a syringe piston, spleen tissues were gently mashed with $1 \mathrm{ml}$ of L-15 medium through a $100 \mu \mathrm{m}$ nylon mesh 

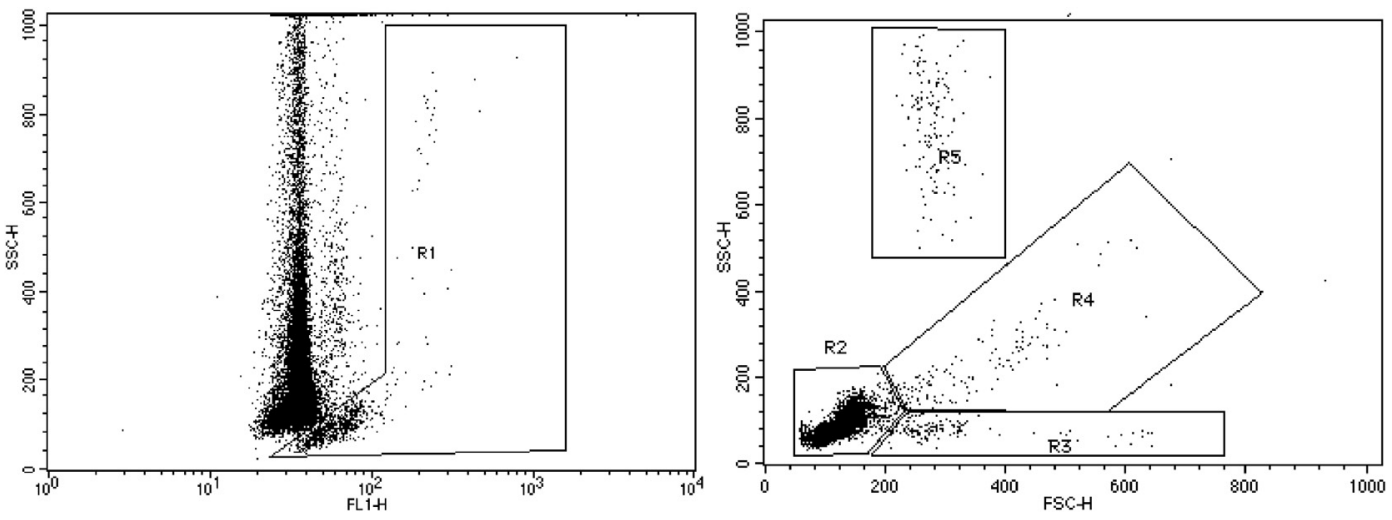

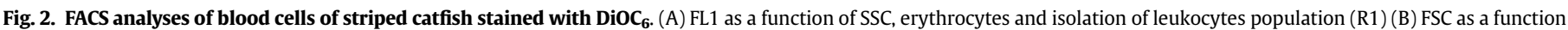
of SSC (R2: thrombocytes and lymphocytes; R3: monocytes; R4: eosinophils; R5: heterophils).
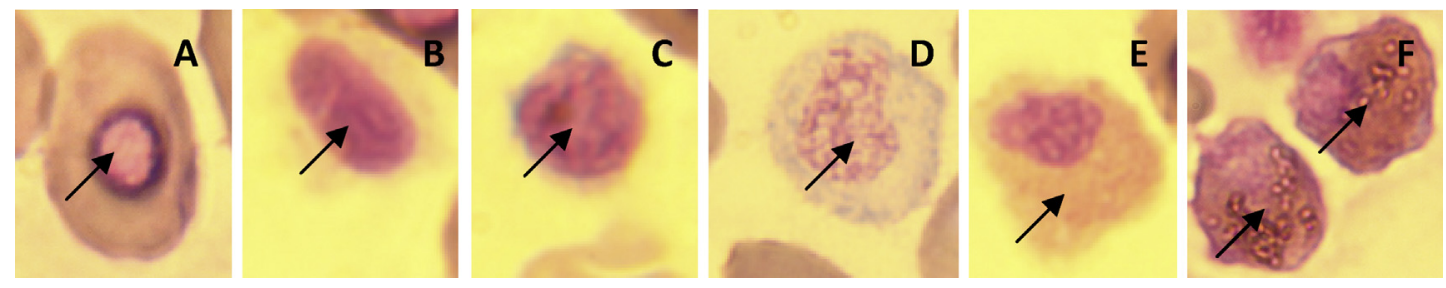

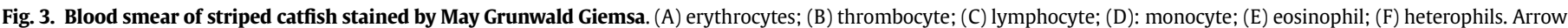
indicates the corresponding cell.

grid settled at the bottom of a Petri dish. The cell suspension was washed twice and $100 \mu \mathrm{l}$ of the final cell suspension were incubated in duplicates with $100 \mu \mathrm{l}$ of nitroblue tetrazolium $\left(1 \mathrm{mg} \mathrm{ml}^{-1}\right.$ in PBS, pH 7.4) during $1 \mathrm{~h}$ at RT. Then, samples were washed in PBS, methanol and finally air-dried at RT. The blue formazan in each tube was dissolved in $240 \mu \mathrm{l}$ of $\mathrm{KOH} 2 \mathrm{M}$ and $280 \mu \mathrm{l}$ of N-dimethylformamide and absorbance was measured at $550 \mathrm{~nm}$. Negative control samples were not incubated but directly brought to methanol fixation step. A standard curve was performed using serial dilutions of nitrobluetetrazolium directly dissolved in $\mathrm{KOH} 2 \mathrm{M}$ and $\mathrm{N}$-dimethylformamide.

\subsubsection{Kidney HSP70 and HMGB-1}

2.5.4.1. Kidney lysates. Using Speed Mill Vac Bound Homogenizer, kidney lysates were obtained by homogenizing kidney tissue for $2 \times 30 \mathrm{~s}$ in the following buffer (1:3): Tris- $\mathrm{HCl} 50 \mathrm{mM}, \mathrm{NaCl}$ $150 \mathrm{mM}$, SDS 0.1\%, Triton X-100 0.1\%, apopritin $0.001 \mathrm{mg} \mathrm{ml}^{-1}, \mathrm{pH}$ 8. Lysates were then sonicated $3 \times 10 \mathrm{~s}$ at $45 \mathrm{kHz}$ and $5 \times 1 \mathrm{~s}$ at $65 \mathrm{kHz}$ on ice and centrifuged at $10000 \mathrm{~g}$ for $10 \mathrm{~min}$ to remove main debris. Total protein abundance in the samples was measured by Pierce method.

2.5.4.2. Blotting. Western blot analyses were performed to validate the specificity of the antibodies. So, $20 \mu \mathrm{g}$ of kidney lysate proteins were mixed with dithiothreitol $0.5 \mathrm{M} 0.1 \%$ and NuPage Lithium Dodecyl Sulfate (1:3) and heated at $70^{\circ} \mathrm{C}$ for $7 \mathrm{~min}$. Samples were then centrifuged at $13000 \mathrm{~g}$ for $5 \mathrm{~min}$ to remove debris. Chemiluminescent ladder (ECL DualVue Marker, Amersham) and $20 \mu \mathrm{g}$ of kidney proteins were separated on a $4-12 \%$ NuPage Novex Bis Tris gel during $1 \mathrm{~h} 30$ at $100 \mathrm{~V}$ and transferred onto a PVDF (polyvinylidene difluoride) membrane using an electrophoretic transfer system during $2 \mathrm{~h} 15$ at $0.8 \mathrm{~mA} \mathrm{~cm}^{-2}$ (BioRad). Then the membrane was blocked overnight with PBST (PBS pH 7.4, 0.1\% Tween-20) containing $5 \%$ skimmed milk at $4{ }^{\circ} \mathrm{C}$. The next day, the membrane was rinsed $2 \times 5 \mathrm{~min}$ in PBST and probed with anti-HSP70 3A3 (ThermoScientific) 1:5000 diluted in $2 \%$ blocking buffer for $1 \mathrm{~h}$ at RT under constant agitation. After washing $2 \times 5$ min with PBST, membrane was incubated with horseradish peroxidase (HRP)conjugated sheep anti-mouse IgG antibody (GE Healthcare) $1: 10000$ diluted in $2 \%$ blocking buffer for $1 \mathrm{~h}$ at RT. Membrane was rinsed $2 \times 10$ min in PBST, 20 min in PBS and revealed with ECL Plus Western Blotting substrate (Thermo Scientific) in ChemiDoc MP Imaging System (BioRad). The same procedure was applied for HMGB-1 western blotting except that the PVDF membrane was probed with anti-HMGB-1 19N15F4 (ThermoScientific) 1:500 diluted in $2 \%$ blocking buffer for $1 \mathrm{~h}$ at RT as a primary antibody. Quantification was performed by dot blotting. Proteins extract $(1 \mu \mathrm{l})$ was directly spotted to the wetted PVDF membrane and allowed to dry out during $30 \mathrm{~min}$ at RT. PVDF membrane was then transferred in a blocking solution (PBST, 5\% skimmed milk) during $1 \mathrm{~h}$ at RT and probed in the same manner than for western blotting. Dot quantification was done using Image J software.

\subsection{Statistical analyses}

Heterogeneity of variances was tested by Levene test and normality was checked by Shapiro-Wilk test. The changes in physiological, osmoregulatory and immune parameters were analysed by two-way analysis of variance ANOVA followed with pairwise multiple comparisons procedures by Scheffe test $(p<0.05)$ in SigmaStat. Data are represented as the mean \pm SD and tanks were used as the statistical unit $(n=4)$.

\section{Results}

\subsection{Growth performance}

The feed intake was significantly higher in fish held in 
freshwater $\left(23.6 \pm 2.2 \mathrm{~g} \mathrm{fish}^{-1}\right)$ compared to fish held in low saline $\left(17.3 \pm 1.3 \mathrm{~g} \mathrm{fish}^{-1}\right)$ and saline $\left(18.2 \pm 2.5 \mathrm{~g} \mathrm{fish}^{-1}\right)$ water. The weight gain $(($ final weight - initial weight)/initial weight $\times 100)$ and the specific growth rate (ln (final weight) - $\ln$ (initial weight)/ time $\times 100$ ) did not significantly vary between groups and averaged respectively $25.7 \pm 1.2 \%$ and $1.1 \pm 0.03 \%$. Fulton's coefficient (K) $\left(100 \times\right.$ weight/length $\left.{ }^{2.88}\right)$ was calculated on each sampling day (days $0,10,20$ and 23 ) and averaged $1.04 \pm 0.05$. K was significantly lower on day 23 compared with day 0,10 and 20 ( $p<0.001$ ).

\subsection{Autopsy}

Autopsies were performed on day 20 ( $\mathrm{n}=6$ fish per treatment) in collaboration with the CER laboratory. In the group exposed to saline water $(0-20 \mathrm{ppt}), 100 \%$ of the fish were suffering from high congestions on fins and tail as well as on the membranous flap of skin of the opercula (Table 1). Only $15 \%$ of the fish were suffering from congestion of barbels and abdomen. No symptoms were observed on the skin mucosal fluidity neither on gill integrity (fluidity, lamellar integrity and vascularisation). Dissection of mouth and ocular structures revealed no macroscopic damages or lesions. No ulcers or lesions were observed on the organs. During infection, all fish showed typical clinical signs of ESC (Enteric Septicaemia of Catfish) including decrease in gill vascularisation, abdominal septicaemia, high congestion of eyes, fins and tail, white gills and nodular round lesions (1-3 mm) on kidney, spleen and, to a smaller extent, on liver.

\subsection{Osmoregulatory response}

The osmoregulatory response of striped catfish to increasing salinity was investigated through plasma osmolality (Fig. 4, A) and gill $\mathrm{Na}^{+} \mathrm{K}^{+}$ATPase (Fig. 4, B). In freshwater, plasma osmolality was comprised between 254 and 271 mosm. With increasing salinities, plasma osmolality gradually increased to reach $288 \pm 6$ mosm at $10 \mathrm{ppt}$ and $370 \pm 3$ mosm at $20 \mathrm{ppt}$ on day 20 (p $<0.001)$. The bacterial infection did not induce significant changes in plasma osmolality. Prior to infection, gill $\mathrm{Na}^{+} \mathrm{K}^{+}$ATPase activity was comprised between 0.27 and $0.75 \mathrm{U} \mathrm{mg}^{-1}$ gill $\mathrm{min}^{-1}$ in freshwater and low saline water respectively. At 20 ppt on day 20, activity increased up to $1.68 \pm 0.32 \mathrm{U} \mathrm{mg}^{-1}$ gill $\mathrm{min}^{-1}$ ( $\mathrm{p}<0.05$ ). During infection, gill $\mathrm{Na}^{+} \mathrm{K}^{+}$ATPase activity significantly decreased from $0.69 \mathrm{U} \mathrm{mg}^{-1}$ gill min $^{-1}$ in freshwater to 0.38 at $20 \mathrm{ppt}(\mathrm{p}<0.001)$.

\subsection{Hematology}

Salinity did not induce any significant effect on the number of erythrocytes and hematocrit (Table 2). Before infection, the abundance of heterophils increased with salinity, peaking at 29.3 million

Table 1

Autopsy of striped catfish exposed to increasing salinity and macroscopic symptoms of ESC disease after 20 days of exposure to salinity increase ( $n=6$ fish/treatment).

\begin{tabular}{lllll}
\hline & FW & LSW & SW & Infected \\
\hline Congestions of fins and tail & - & - & + & ++ \\
Congestion of opercula & - & - & + & ++ \\
Congestion of barbels and eyes & - & - & + & ++ \\
Diffuse abdominal congestion & - & - & + & ++ \\
Mucosal fluidity (skin) & + & + & + & + \\
Gill integrity (mucus, vascularisation) & + & + & + & - \\
Cutaneous petechial haemorrhages & - & - & - & + \\
Lesion or ulceration in organs & - & - & - & + \\
Abdominal septicaemia & - & - & - & + \\
\hline
\end{tabular}

Freshwater (FW), low saline water (LSW, 0-10 ppt) and saline water (SW, $0-20$ ppt). $-/+$ : absence/presence; $+/++$ : comparative gravity of the lesions.
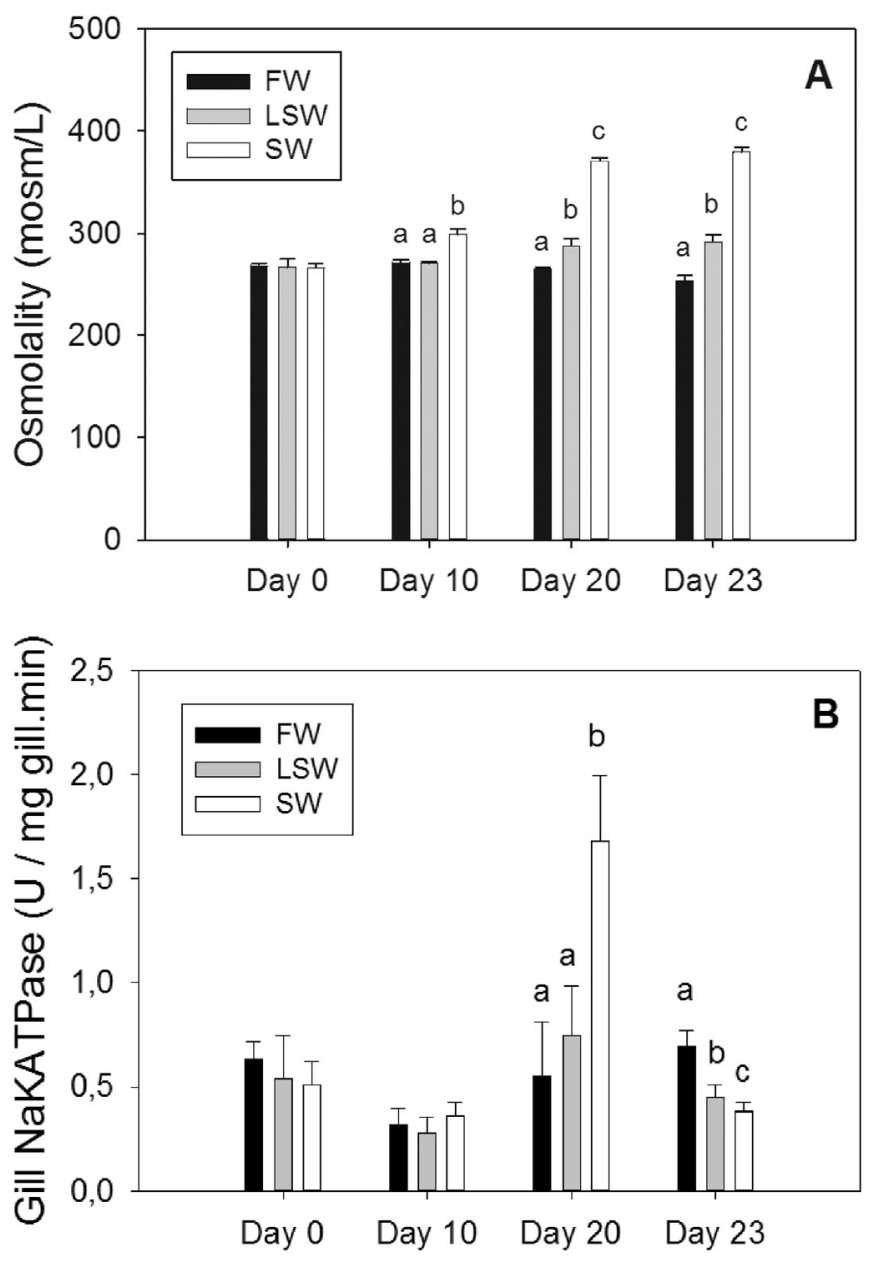

Fig. 4. Osmoregulatory responses of striped catfish exposed (or not) to elevated salinity and experimentally infected with Edwardsiella ictaluri. Plasma osmolality (A) and gill $\mathrm{Na}^{+} \mathrm{K}^{+}$ATPase activity (B) of striped catfish exposed to freshwater (FW, black), low saline water (LSW, grey) and saline water gradient (SW, white) during 20 days and 3 days post-infection (day 23). The values were presented as the mean \pm SD with $\mathrm{n}=4$ ( 4 tanks, 6 fish/tank). The statistical letters (a,b,c) indicate a significant change $(p<0.05)$ between salinity treatments on the same sampling day.

cells $\mu \mathrm{l}^{-1}$ blood at $20 \mathrm{ppt}$, which corresponds to a level 4 fold higher than in freshwater and low saline water $(\mathrm{p}<0.01)$ (Table 2). During infection, fish also exhibited significant changes in their blood cell populations (Table 2). The number of thrombocytes/lymphocytes significantly decreased by one third on day 23 in all groups compared with day 0,10 and 20 ( $\mathrm{p}<0.001)$. Moreover, increase in salinity also significantly lowered the number of thrombocytes/ lymphocytes from 124.8 million cells $\mu^{-1}$ blood in freshwater to 82.53 million cells $\mu \mathrm{l}^{-1}$ blood in saline water $(\mathrm{p}<0.01)$. As the decrease is higher than the proportion of lymphocytes in the cluster, as suggested by microscopic stain, thrombocytes may be, at least partly, responsible for the drop of the cluster in cytometry. The number of eosinophils and heterophils significantly increased during infection (day 23) compared with day 0,10 and 20 but was not significantly affected by salinity $(\mathrm{p}<0.01)$. During infection, the number of monocytes was enhanced with salinity by two fold to reach 30.7 million cells $\mu \mathrm{l}^{-1}$ blood.

\subsection{Immune parameters}

Salinity significantly enhanced plasma lysozyme activity, alternative complement pathway and spleen respiratory burst. The 
Table 2

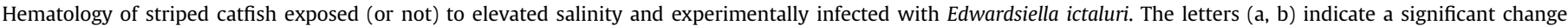
( $p<0.05$ ) between salinity treatment on a same sampling day.

\begin{tabular}{|c|c|c|c|c|}
\hline & & FW & LSW & SW \\
\hline \multirow[t]{4}{*}{ Erythrocytes (million cells $\mu \mathrm{l}^{-1}$ blood) } & Day 0 & $3.84 \pm 0.20$ & $4.10 \pm 0.20$ & $4.09 \pm 0.40$ \\
\hline & Day 10 & $3.85 \pm 0.09$ & $3.81 \pm 0.12$ & $4.15 \pm 0.28$ \\
\hline & Day 20 & $4.08 \pm 0.18$ & $3.87 \pm 0.36$ & $4.36 \pm 0.15$ \\
\hline & Day 23 & $4.37 \pm 0.13$ & $4.13 \pm 0.27$ & $4.6 \pm 0.22$ \\
\hline \multirow[t]{4}{*}{ Hematocrit (\%) } & Day 0 & $37.6 \pm 1.59$ & $33.67 \pm 1.44$ & $33.60 \pm 2.51$ \\
\hline & Day 10 & $33.67 \pm 1.28$ & $31.54 \pm 1.56$ & $33.20 \pm 2.12$ \\
\hline & Day 20 & $36.93 \pm 1.94$ & $35.78 \pm 1.60$ & $36.62 \pm 1.77$ \\
\hline & Day 23 & $32.29 \pm 1.17$ & $32.17 \pm 1.05$ & $31.90 \pm 2.38$ \\
\hline \multirow[t]{4}{*}{ Thrombocytes and lymphocytes (thousand cells $\mu \mathrm{l}^{-1}$ blood) } & Day 0 & $171.3 \pm 23$ & $170.9 \pm 38.6$ & $152.8 \pm 17.5$ \\
\hline & Day 10 & $167.7 \pm 32.9$ & $167.5 \pm 7.3$ & $164.8 \pm 11.6$ \\
\hline & Day 20 & $153.3 \pm 8.3$ & $171.0 \pm 16.1$ & $149.9 \pm 29.4$ \\
\hline & Day 23 & $124.8 \pm 15.2^{\mathrm{a}}$ & $109.4 \pm 24.8$ & $82.53 \pm 11.9^{b}$ \\
\hline \multirow[t]{4}{*}{ Monocytes (thousand cells $\mu \mathrm{I}^{-1}$ blood) } & Day 0 & $18.1 \pm 13$ & $7.3 \pm 1.9$ & $10.2 \pm 8.2$ \\
\hline & Day 10 & $7.3 \pm 5.4$ & $13.1 \pm 9.1$ & $6.8 \pm 4.6$ \\
\hline & Day 20 & $39.3 \pm 19.2$ & $16.8 \pm 11.1$ & $14.6 \pm 6.0$ \\
\hline & Day 23 & $17.4 \pm 2.3^{\mathrm{ab}}$ & $13.4 \pm 4.9^{\mathrm{a}}$ & $30.7 \pm 8.9^{b}$ \\
\hline \multirow[t]{4}{*}{ Eosinophils (thousand cells $\mu \mathrm{l}^{-1}$ blood) } & Day 0 & $7.6 \pm 2.6$ & $9.0 \pm 1.9$ & $8.9 \pm 8.4$ \\
\hline & Day 10 & $7.8 \pm 1.9$ & $7.5 \pm 1.4$ & $5.2 \pm 0.7$ \\
\hline & Day 20 & $7.6 \pm 3.4$ & $5.4 \pm 1.4$ & $6.9 \pm 0.7$ \\
\hline & Day 23 & $8.7 \pm 0.9$ & $11.0 \pm 7.2$ & $12.9 \pm 1.6$ \\
\hline \multirow[t]{4}{*}{ Heterophils (thousand cells $\mu \mathrm{l}^{-1}$ blood) } & Day 0 & $5.4 \pm 2.4$ & $6.2 \pm 4.5$ & $4.1 \pm 2.1$ \\
\hline & Day 10 & $3.3 \pm 3.0$ & $1.8 \pm 1.1$ & $3.2 \pm 1.0$ \\
\hline & Day 20 & $7.2 \pm 3.7^{\mathrm{a}}$ & $4.6 \pm 1.7^{a}$ & $29.3 \pm 6.3^{b}$ \\
\hline & Day 23 & $17.8 \pm 4.4$ & $11.3 \pm 9.0$ & $11.9 \pm 5.1$ \\
\hline
\end{tabular}

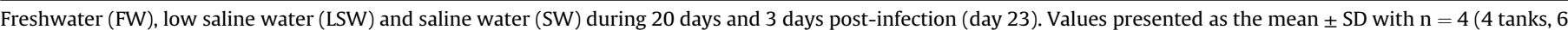
fish/tank). Significant results in bold. The statistical letters $(a, b)$ indicate a significant change $(p<0.05)$ between salinity treatments.

strongest significant effect was observed on plasma lysozyme activity which gradually but significantly increased with elevating salinity ( $\mathrm{p}<0.001$ ) (Fig. 5 A). On day 0 , lysozyme activity varied between 194 and $219 \mathrm{U} \mathrm{ml}^{-1}$ plasma. On day 10, lysozyme activity peaked at $264 \mathrm{U} \mathrm{ml}^{-1}$ plasma in fish held in saline water compared to $217 \mathrm{U} \mathrm{ml}^{-1}$ plasma in fish held in low saline water and
$199 \mathrm{U} \mathrm{ml}^{-1}$ plasma in fish kept in freshwater. On day 20, it reached 519 and $346 \mathrm{U} \mathrm{ml}^{-1}$ plasma respectively in fish of high and low saline water groups while it averaged $268 \mathrm{U} \mathrm{ml}^{-1}$ plasma in freshwater fish. During the bacterial challenge, lysozyme activity significantly increased by 3-fold compared to values observed in fish prior to infection $(\mathrm{p}<0.001)$ and the stimulating effect of
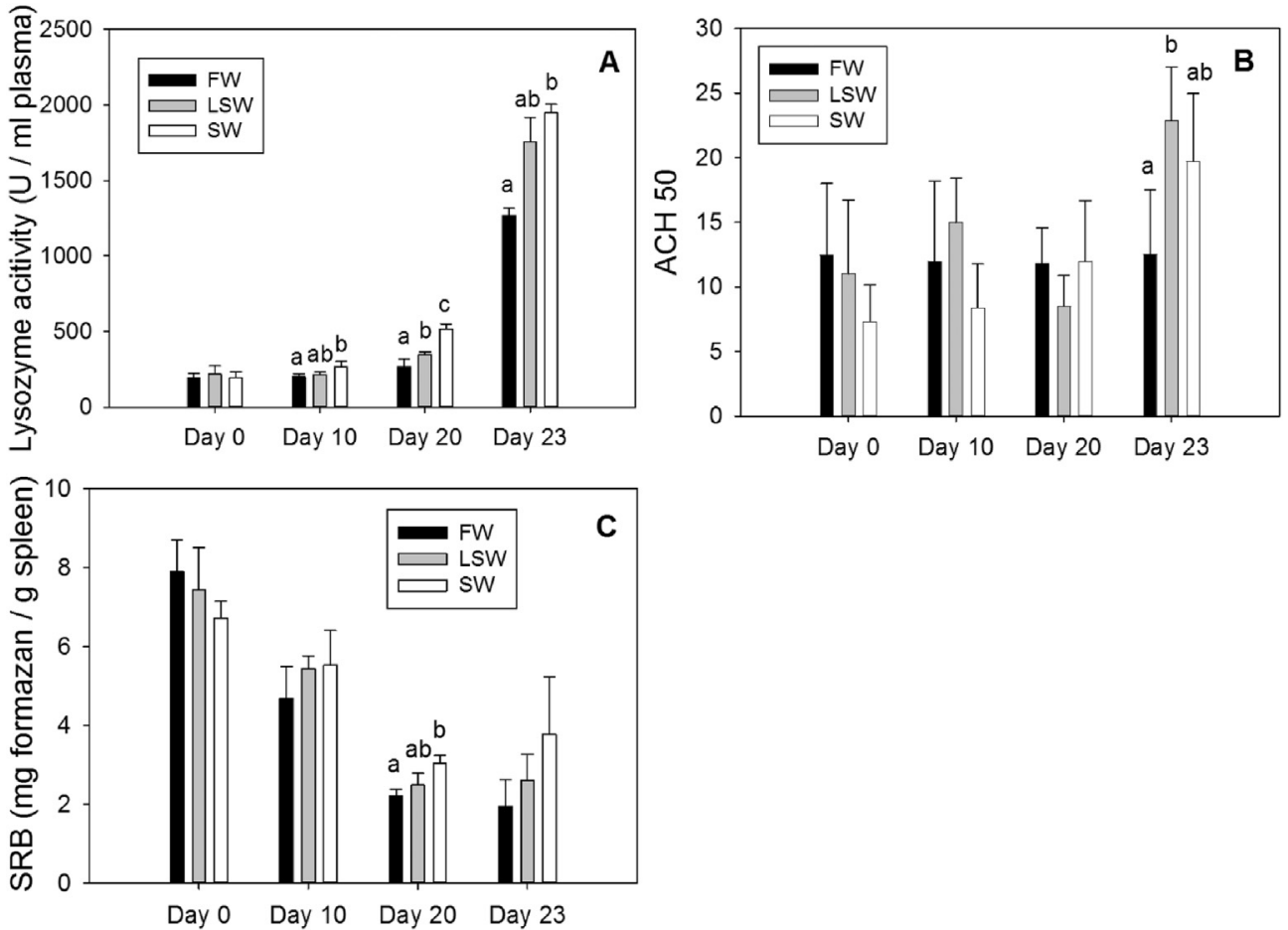

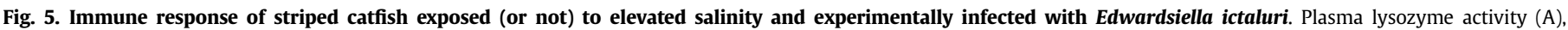

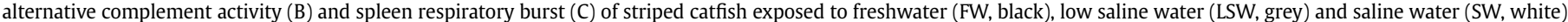

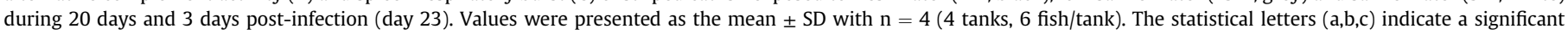
change $(\mathrm{p}<0.05)$ between salinity treatments on a same sampling day. 
salinity was maintained $(\mathrm{p}<0.001)$. Indeed, in freshwater condition lysozyme activity averaged $1268 \mathrm{U} \mathrm{ml}^{-1}$ plasma in freshwater fish, $1756 \mathrm{U} \mathrm{ml}^{-1}$ plasma in fish from low saline water and $1948 \mathrm{U} \mathrm{ml}^{-1}$ plasma those from saline water. No significant effects of salinity on the alternative complement activity, which varied between 7.3 and $12.5 \mathrm{U} \mathrm{ml}^{-1}$ plasma, were observed in fish prior to infection (Fig. 5 B). However, ACH50 (Alternative Complement Hydrolysis 50\%) significantly increased in infected fish (day 23), particularly in low saline water and saline water ( $p<0.001)$. ACH50 response was significantly higher during bacterial infection in fish from low saline water $\left(12.5 \pm 5.0 \mathrm{U} \mathrm{ml}^{-1}\right.$ plasma) compared to freshwater fish $\left(22.8 \pm 4.2 \mathrm{U} \mathrm{ml}^{-1}\right.$ plasma $)(\mathrm{p}<0.01)$. Spleen respiratory burst significantly decreased up to 4 fold during the experiment in all groups ( $p<0.001$ ) (Fig. 5 C). On day 20, respiratory burst significantly increased up to $3.0 \pm 0.2 \mathrm{mg}$ formazan $\mathrm{g}^{-1}$ spleen in fish held in saline water compared to those held in freshwater $\left(2.2 \pm 0.2 \mathrm{mg}\right.$ formazan $\mathrm{g}^{-1}$ spleen $)(\mathrm{p}<0.001)$.

On the opposite, salinity did not induce any significant changes in the abundance of HSP70 and HMGB-1 in kidney. Relative to its abundance in freshwater fish from day 0, production of HSP70 varied from 0.46 to 1.63 fold on days 10, 20 and 23 (Fig. 6 A). However, production of HMGB-1 was significantly higher in infected fish (day 23) compared to days 0,10 and 20 ( $p<0.001$ ). Relative production of HMGB-1 varied from 0.60 to 1.96 fold in fish prior to injection and increased 2.80-5.94 fold in infected fish, compared with the abundance of HMGB-1 in freshwater on day 0 (Fig. 6 B).

\subsection{Sensitivity to Edwardsiella ictaluri}

Fig. 7 shows cumulative mortalities during 10 days after bacteria inoculation in the three salinity groups. At $72 \mathrm{~h}$ post inoculation, mortalities were significantly higher in saline water $(67 \pm 14 \%)$ compared to freshwater $(0 \pm 0 \%)$ and saline water $(13 \pm 16 \%)$ $(\mathrm{p}<0.05)$. At $96 \mathrm{~h}$ post inoculation, mortalities begun in fish held in freshwater $(42 \pm 10 \%)$ but were significantly lower than those recorded in saline water $(75 \pm 10 \%)(\mathrm{p}<0.05)$. On day 5 , cumulative mortality was significantly higher in saline water $(92 \pm 10 \%)$ compared to low saline water $(67 \pm 14 \%$ ). No additional mortalities were recorded from day 5 and up to day 10 post inoculation in the three salinity groups.

\section{Discussion}

Plasma osmolality values measured in this study were in the same range than those reported by other authors in striped catfish

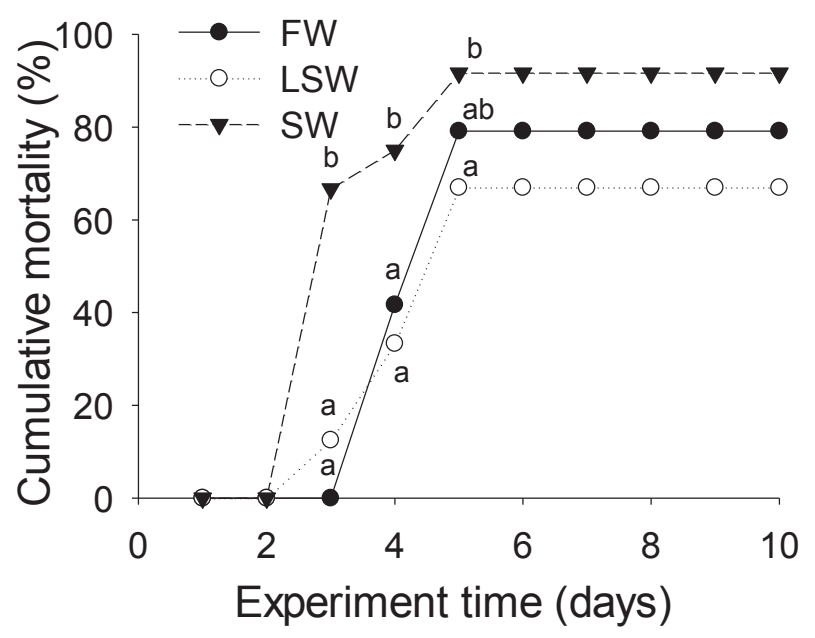

Fig. 7. Cumulative mortality of striped catfish exposed (or not) to elevated salinity during 10 days after inoculation of Edwardsiella ictaluri. Mean cumulative mortality of striped catfish exposed to freshwater (FW), low saline water (LSW) and saline water (SW) during 10 days. The values were represented as the mean cumulative mortality (4 tanks, 6 fish/tank).

and other siluridae, differing by less than $10 \%[27,28]$. Increase in salinity was responsible for elevated blood plasma osmolality while gill $\mathrm{Na}^{+} \mathrm{K}^{+}$ATPase activity only increased at $20 \mathrm{ppt}$. When striped catfish were submitted to low saline stress up to $10 \mathrm{ppt}$ (270 mosm), plasma osmolality equilibrated with external salinity. However, higher salinity up to 20 ppt (540 mosm) induced a significant increase in plasma osmolality although to a lower level than that of the environment ( 370 mosm \pm 3 mosm). This indicated that gill electrolyte clearance is insufficient to cope with the increased salt load. Similarly, seawater survival of channel catfish is limited due to the absence of efficient electrolyte excretion. Transfer of channel catfish from freshwater to seawater induced an elevation in plasma osmolality while the activity of functional renal glomeruli decreased $[27,29]$. In the current study, infection subsequent to salinity exposure lowered gill $\mathrm{Na}^{+} \mathrm{K}^{+}$ATPase activity whereas plasma osmolarities remained unchanged. As live E. ictaluri gain access to blood circulation system across the gills, decrease in gill vascularisation is frequent in infected fish (including striped catfish in this study) and may be responsible for gill ion transport collapse [30,31].

In saline water (20 ppt), striped catfish juveniles suffered from high congestions throughout the body. Prolonged high osmotic pressure in blood vessels may damage the endothelium and induce
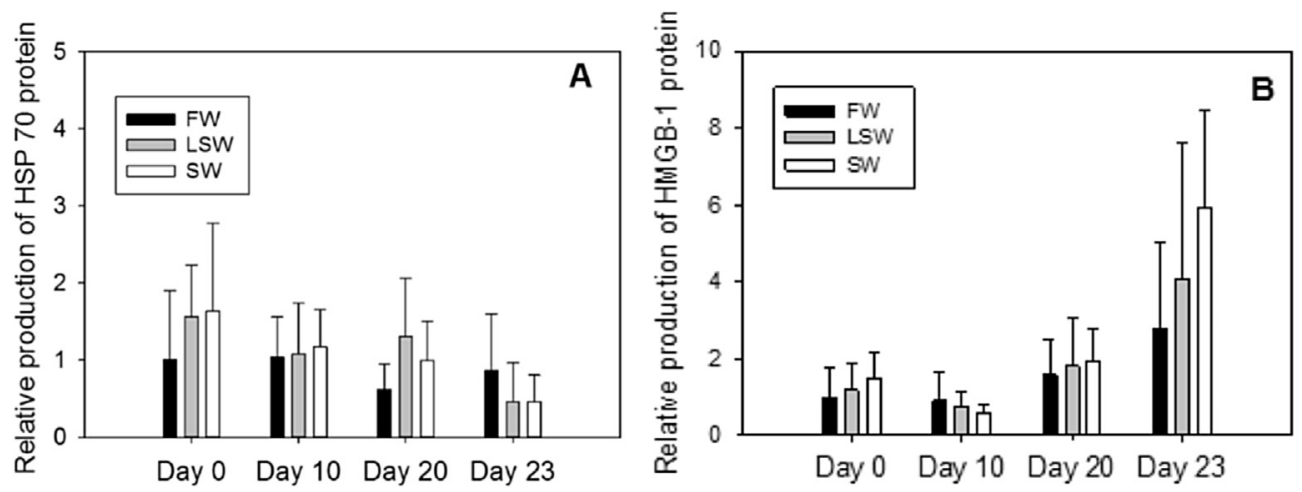

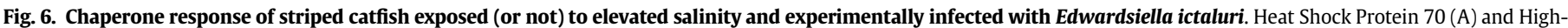

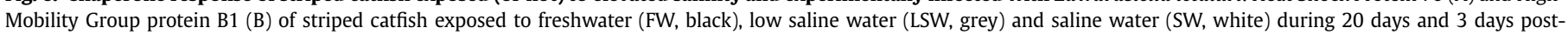
infection (day 23). Values were presented as the mean \pm SD with $n=4$ ( 4 tanks, 6 fish/tank). 
sterile inflammation. Particularly, high congestions have been observed on the opercular membrane, a membranous flap of skin located along the edge of the opercula that might play key role in resistance to hypoxia [32]. Whether increased osmotic pressure in the opercula may impair the resistance of striped catfish to hypoxia is unknown but should be investigated, as oxygen levels in typical Vietnamese aquacultures are inferior to $5 \mathrm{kPa}$ [33].

Blood composition and abundance of immune cells were modified by salinity in both healthy and infected fish. Prior to infection, the abundance of heterophils in the circulation of fish held in saline water increased by nearly 4 fold. During ESC, the abundance of macrophages increased by 2 fold in fish held in saline water while the abundance of thrombocytes was severely and gradually depleted. In this study, increase in monocytes and heterophils during hyperosmotic stress in healthy and infected fish respectively may indicate that the increased osmotic pressure is perceived as a threat to body integrity. In addition, the abundance of granulocytes (i.e. eosinophils and heterophils) increased in infected fish compared to the abundance before infection. Therefore, both stressors (infection and salinity) were responsible for accumulation of blood inflammatory cells including monocytes, eosinophils and heterophils. During prolonged cellular stress, it is known that persistence of such inflammatory cells may lead to excessive immune reaction and tissue damage [19]. On the contrary, salinity and infection had a synergic negative effect on the number of thrombocytes. In fish, decrease in the abundance of circulating thrombocytes is a frequent observation during pathogenic infection $[34,35]$ while the effects of salinity on thrombocytes have not been investigated yet. In infected fish, the increased blood osmotic pressure may activate the coagulation system in response to blood vessel damage and decrease the number of free circulating thrombocytes. Although their implication in hemostasis and wound healing is well-studied, the role of thrombocytes in immune functions is often neglected. Due to their extensively high number in the circulation, thrombocytes may play a major role in inflammatory processes and immunity. In fish, thrombocytes express a high number of immune-relevant genes involved in inflammation and antigen presentation, have the capacity to phagocytose live bacteria and foreign particles and may have bactericidal activity [34-36].

In the present study, innate immune components were stimulated with increasing salinities or in combination with bacterial challenge. Plasma lysozyme activity of freshwater fish are in accordance with those of Sirimanapong et al. (2014) [37] and differ by less than $10 \%$. Salinity and infection rapidly and gradually stimulated lysozyme activity. In fish, higher lysozyme activities during both acute and chronic hyperosmotic stress have also been described in euryhaline species [5,6,38,39]. In this study, ACH50 values of freshwater fish are within the same range of values than those measured by Hang et al. (2013) [40] on the same species. ACH 50 values increased during infection. In addition, a combination stimulatory effect of elevated salinity and infection was observed. In fish, variations of ACH50 during an osmotic stress have been poorly investigated. In gilthead seabream Sparus aurata, it has been shown that complement activities may increase or decrease when salinity increase, depending on acclimation time [4]. The respiratory burst was within the same range of values those already observed for other species $[41,42]$. A decrease in respiratory burst along the experiment have been observed and may be caused by insufficient acclimation time prior to the onset of the experiment. Our results suggest that salinity might stimulate spleen respiratory burst in striped catfish during hyperosmotic stress, similarly to the responses observed in several euryhaline species [5,43], but such modulation was not markedly affected by bacterial challenge. During bacterial infection, excessive respiratory burst induced by the persistence of immune cells such as activated granulocytes and macrophages may lead to oxidative stress and tissue injury if not adequately countered by antioxidant activities [19].

In our experiment, salinity stressor induced earlier onset of mortality in striped catfish during ESC. Moreover, cumulative mortalities after 10 days were significantly higher in fish held in saline water (92\%) compared to fish held in low saline water (67\%). In grouper fish, acute osmotic shock during 48 h (33 ppt-20 or $40 \mathrm{ppt}$ ) increased susceptibility to birnavirus from 10 to $90 \%$ [7]. Therefore, high salinity stressor may increase sensitivity to ESC. At the opposite, low salinity water may have a protective effect in striped catfish by preventing bacteria multiplication.

In this study, HSP70 level remained unchanged with saline gradient alone the experiment. During acute or chronic hyperosmotic stress, increase in branchial HSP70 expression has been documented in several euryhaline species [43-45] while HSP70 modulation in other tissues remained unclear. In silver seabream acclimated to a large range of salinities, expression of HSP70 multigene family remained unchanged in kidney [43]. Similarly to HSP70, no significant changes were observed in HMGB1 level during salinity exposure whereas HMGB1 level increased in infected fish compared to no infected fish. In addition, following infection, a nonsignificant increase was observed with salinity. In mammals, active secretion of HMGB1 mainly occurs when immunologically competent cells are exposed to pathogen or microbial associated molecular patterns $[46,47]$. On the contrary, sterile injury did not induce HMGB1 production but only leaded to passive release of inactive HMGB1 $[46,47]$. In the present study, it might be possible that sterile tissue damages induced by the hyperosmotic pressure did not induce active overproduction of HSP70 and HMGB1 but that passive extracellular release of HSP70 and HMGB1 occurred, making available some inflammatory mediators. Further, high standard deviation may reflect difference in HSP70 and HMGB1 response depending on individual fish susceptibility to the pathogen.

\section{Conclusion}

The present study demonstrated that salinity alone or salinity associated to infection increased some immune functions (i.e. lysozyme activity, complement activity, respiratory burst, abundance of monocytes and heterophils). Nevertheless, increase in immune factors does not necessarily indicate higher resistance to microbial disease, as suggested by the higher mortality rate in saline water. Chronic increase in the osmolality of body fluids may result in the persistence of sterile inflammatory processes such as granulocytes and macrophages accumulations, respiratory burst, release of inflammatory mediators and proteases. Therefore, it can be expected that such excessive inflammatory response may lead to immune exhaustion and that the resulting tissue damages may disrupt basal immune homeostasis, thereby creating an unfavourable environment for efficient immune defence in case of pathogen contamination.

In conclusion, these novel results show the importance of the multi-stress approach in fish. To a larger extent, salt is commonly used as an antiseptic to prevent and treat microbial diseases in fish farms. In striped catfish ponds, production under moderate salinities has already been suggested in order to prevent microbial contamination. However, salt sterilization process targeting halophile pathogens should be managed carefully in order to avoid prolonged exposure of fish to hyperosmotic conditions which might be responsible for immune defence impairment.

\section{Acknowledgements}

We are grateful to the staff of CEFRA-Tihange (Ulg) and 
particularly to Christian Prignon for providing useful advices in catfish rearing and to Christian Didembourg in URBM (University of Namur) for his assistance during culture in bacterial strain and flow cytometer analyses. Thanks are due to FRIA (Fonds de la Recherche dans l'Industrie et l'Agriculture, Wallonia-Brussels Federation) grant number 14768837 and Unamur (Université de Namur) for providing a PhD grant to M.S.

\section{References}

[1] FAO - Food and Agriculture Organization of the United Nations, The State of World Fisheries and Aquaculture, Food and Agriculture Organization of the United Nations, Rome, 2014.

[2] Vietnam Association of Seafood Exporters and Producers (VASEP), Pangasius Export Statistics, VASEP, Vietnam, 2015.

[3] SIWRR (the Southern Institute of Water Resource Research), 2016 http:// www.tongcucthuyloi.gov.vn/ (accessed 24.03.16).

[4] A. Cuesta, R. Laiz-Carrion, M. Martin del Rio, J. Meseguer, J. Mancera, M. Esteban, The salinity influences humoral immune parameters of gilthead seabream (Sparus aurata), Fish. Shellfish Immun. 18 (2005) 255-261.

[5] I.-F. Jiang, V.-B. Khumar, D.-N. Lee, C.-F. Weng, Acute osmotic stress affects tilapia (Oreochromis mossambicus) innate immune responses, Fish. Shellfish Immun. 25 (2008) 41-846.

[6] T. Yada, T. Azuma, Y. Takaji, Stimulation of non-specific immune functions in seawater-acclimated rainbow trout Oncorhynchus mykiss, with reference to the role of growth hormone, Comp. Biochem. Phys. B 129 (2001) 695-701.

[7] H.Y. Chou, T.Y. Peng, S.J. Chang, Y.L. Hsu, J.L. Wu, Effect of heavy metal stressors and salinity shock on the susceptibility of grouper (Epinephelus sp.) to infectious pancreatic necrosis virus, Virus Res. 63 (1999) 121-129.

[8] J. Delamare-Deboutteville, D. Wood, A.C. Barnes, Response and function of cutaneous mucosal and serum antibodies in barramundi (Lates calcarifer) acclimated in seawater and freshwater, Fish. Shellfish Immun. 21 (2006) $92-101$.

[9] E. Abraham, J. Arcaroli, A. Carmody, H. Wang, K.J. Tracey, HMG-1 as a mediator of acute lung inflammation, J. Immunol. 165 (2000) 2950-2954.

[10] R.J. Roberts, C. Agius, C. Saliba, P. Bossier, Y.Y. Sung, Heat shock proteins (chaperones) in fish and shellfish and their potential role in relation to fish health: a review, J. Fish. Dis. 33 (2010) 789-801.

[11] D. Tang, R. Kang, H.J. Zeh, M.T. Lotze, High-mobility group box 1, oxidative stress,and disease, Antioxid. Redox. Sign. 14 (2011) 11315-11335.

[12] M.P. Mayer, B. Bukau, Hsp 70 chaperones: cellular function and molecular mechanism, Cell. Mol. Life Sci. 62 (2005) 670-684.

[13] H. Wang, H. Liao, M. Ochani, M. Justiniani, X. Lin, L. Yang, Y. Al-Abed, H. Wang, E.J. Metz, K.J. Tracey, L. Ukkoa, Cholinergic agonists inhibiti HMGB1 release and improve survival in experimental sepsis, Nat. Med. 10 (2004) 1216-1221.

[14] P. Norouzitallab, B. Kartik, D.M. Muthappa, P. Bossier, Non lethal heat shock induces HSP70 and HMGB1 protein production sequentially to protect Artemia franciscana against Vibrio campbelii, Fish. Shellfish Immun. 42 (2015) 395-399.

[15] K. Baruah, P. Norouzitallab, L. Linayati, P. Sorgeloos, P. Bossier, Reactive oxygen species generated by a heat shock protein (Hsp) inducing product contributes to Hsp70 production and Hsp70-mediated protective immunity in Artemia franciscana against pathogenic vibrios, Dev. Comp. Immunol. 46 (2014) 470-479.

[16] M.A. Chase, D.S. Wheeler, K.M. Lierl, V.S. Hughes, H.R. Wong, K. Page, Hsp72 induces inflammation and regulates cytokine production in airway epithelium through a TLR4 and NF kappa B dependent mechanism, J. Immunol. 170 (2007) 6318-6324.

[17] L. Zhao, Y. Hu, J. Sun, L. Sun, The high mobility group box 1 protein of Sciaenops ocellatus is a secreted cytokine that stimulates macrophage activation, Dev. Comp. Immunol. 35 (2011) 1052-1058.

[18] J. Xie, J.W. Hodgkinson, N. Kovacevic, M. Belosevic, Identification and functional characterization of the goldfish (Carassius auratus L.) high mobility group box 1 (HMGB1) chromatin binding protein, Dev. Comp. Immunol. 44 (2014) 245-253.

[19] G.Y. Chen, G. Nunez, Sterile inflammation: sensing and reacting to damage, Nat. Rev. 10 (2010) 826-837.

[20] J.-P. Hawke, A.C. McWhorther, A.G. Steigerwalt, D.J. Brenner, Edwardsiella ictaluri sp. nov., the causative agent of enteric septicaemia of catfish, Int. J. Syst. Bacteriol. 31 (1981) 396-400.

[21] S.D. Mc Cormick, Methods for nonlethal gill biopsy and measurement of NaKATPase activity, Can. J. Fish. Aquat. Sci. 50 (1993) 656-658.

[22] (a) T. Inoue, T. Moritomo, Y. Tamura, S. Mamiya, H. Fujino, T. Nakanishi, A new method for fish leucocyte counting and partial differentiation by flow cytometry, Fish. Shellfish Immun. 13 (2002) 379-390;

(b) M.-A. Pierrard, K. Roland, P. Kestemont, M. Dieu, M. Raes, F. Silvestre, Fish peripheral blood mononuclear cells preparation for future monitoring applications, Anal. Biochem. 426 (2012) 153-165.

[23] G.R. Vázquez, G.A. Guerrero, Characterization of blood cells and hematological parameters in Cichlasoma dimerus (Teleostei, Perciformes), Tissue Cell 39 (2007) 151-160.

[24] A.E. Ellis, Lysozyme activity, in: T.C. Stolen, P.D. Fletcher, B.S. Anderson,
B.S. Roberson, W.B. Muiswinkel (Eds.), Technique in Fish Immunology, SOS Publications, New York, 1990, pp. 101-103.

[25] J.O. Sunyer, L. Tort, Natural haemolytic and bactericidal activities of sea bream Sparus aurata serum are effected by the alternative complement pathway, Veterinary Immunol. Immunop. 45 (1995) 333-345.

[26] G.A.W. Rook, J. Steele, S. Umar, H.M. Dockrell, A simple method for the solubilisation of reduced NBT and its use as a colorimetric assay for activation of human macrophages by $\delta$-interferon, J. Immunol. Methods 82 (1985) $161-167$.

[27] S.M. Eckert, T. Yada, B.S. Shepherd, M. Stetson, T. Hirano, E.G. Grau, Hormonal freshwater of osmoregulation in the channel catfish Ictalurus punctatus. Gen. Comp, Endocr 122 (2001) 270-286.

[28] T.H.N. Phuc, D.T.T. Huong, P.B. Mather, D.A. Hurwood, Experimental assessment of the effects of sublethal salinities on growth performance and stress in cultured tra catfish (Pangasianodon hypophthalmus), Fish. Physiol. Biochem. 40 (2014) 1839-1848.

[29] V. Norton, K. Davis, Effect of abrupt change in the salinity of the environmental on plasma electrolytes, urine, volume, volume and electrolytic excretion in channel catfish, Ictalurus punctatus, Comp. Biochem. Phys. 56A (1977) 425-431.

[30] K. Yuasa, E.B. Kholidin, N. Panigoro, K. Hatai, First isolation of Edwardsiella ictaluri from cultured striped catfish Pangasius hypophthalmus in Indonesia, Fish. Pathol. 38 (2003) 181-183.

[31] Y. Shigen, L. Hua, Q. Guo, L. Zhongshi, First case of Edwardsiella ictalur infection in China farmed yellow catfish Pelteobagrus fulvidraco, Aquaculture 292 (2009) 6-10.

[32] S. Lefevre, D.T.T. Huong, T. Wang, N.T. Phuong, M. Bayley, Hypoxia tolerance and partitioning of bimodal respiration in the striped catfish (Pangasianodon hypophthalmus), Comp. Biochem. Phys. A 158 (2011) 207-214.

[33] S. Lefevre, D.T.T. Huong, N.T.K. Ha, T. Wang, N.T. Phuong, M. Bayley, A telemetry study of swimming depth and oxygen level in a Pangasius pond in the Mekong Delta, Aquaculture 315 (2011) 410-413.

[34] I. Fink, C. Ribeiro, M. Forlenza, A. Taverne-Thiele, J. Rombout, H. Savelkoul, G. Wiegertjes, Immune relevant thrombocytes of common carp undergo parasite induced nitric oxide-mediated apoptosis, Dev. Comp. Immunol. 50 (2015) 146-154.

[35] B. Köllner, U. Fisher, J.H. Rombout, J.J. Taverne-Thiele, J.D. Hansen, Potential involvement of rainbow trout thrombocytes in immune functions: a study using a panel of monoclonal antibodies and RT-PCR, Dev. Comp. Immunol. 28 (2004) 1049-1062.

[36] T. Nagasawa, C. Nagayasu, A. Rieger, D. Barreda, T. Somamoto, M. Nakao, Phagocytosis by thrombocytes is a conserved innate immune mechanism in lower vertebrates, Front. Immunol. 5 (2014) 1-11.

[37] W. Sirimanapong, K. Thompson, K. Kledmanee, P. Thaijongrak, B. Collet A. Adams, Optimisation and standardisation of functional immune assays for striped catfish (Pangasianodon hypophthalmus) to compare their immune response to live and heat killed Aeromonas hydrophila as models of infection and vaccination, Fish. Shellfish Immun. 40 (2014) 374-383.

[38] A.M. Marc, C. Quentel, A. Severe, P.Y. Le Bail, G. Boeuf, Changes in some endocrinological and non-specific immunological parameters during seawater exposure in the brown trout, J. Fish. Biol. 46 (1995) 1065-1081.

[39] M. Dominguez, A. Takeruma, M. Tsuchiya, Effects of changes in environmental factors on the non-specific immune response of Nile tilapia, Oreochromis niloticus L, Aquac. Res. 36 (2005) 391-397.

[40] D.T.T. Hang, S. Milla, V. Gillardin, N. Phuong, P. Kestemont, In vivo effects of Escherichia coli lipopolysaccharide on regulation of immune response and protein expression in striped catfish (Pangasianodon hypophthalmus), Fish. Shellfish Immun. 34 (2013) 339-347.

[41] S. Milla, C. Mathieu, N. Wang, S. Lambert, S. Nadzialek, S. Massart, E. Henrotte J. Douxfils, C. Melard, S.N.M. Mandiki, P. Kestemont, Spleen immune status is affected after acute handling stress but not regulated by cortisol in Eurasian perch, Perca fluviatilis, Fish. Shellfish Immun. 28 (2010) 931-941.

[42] J. Douxfils, C. Mathieu, S.N.M. Mandiki, S. Milla, E. Henrotte, N. Wang, M. Vandecan, et al., Physiological and proteomic evidences that domestication process differentially modulates the immune status of juvenile Eurasian perch (Perca fluviatilis) under chronic confinement stress, Fish. Shellfish Immun. 31 (2011) 1113-1121.

[43] E.E. Deane, N.Y. Woo, Differential gene expression associated with euryhalinity in sea bream (Sparus sarba), Am. J. Physiol. Integr. Comp. Physiol. 287 (2004) 1054-1063.

[44] C.J. Niu, J.L. Rummer, C.J. Brauner, P.M. Schultz, Heat Shock Protein induced by a mild heat shock slightly moderates plasma osmolality upon salinity transfer in rainbow trout (Onchorynchus mykiss), Comp. Biochem. Physiol. C 148 (2008) 437-444.

[45] M. Tine, F. Bonhomme, D. McKenzie, J.-D. Durand, Differential expression of the heat shock protein Hsp70 in natural populations of the tilapia, Sarotherodon melanotheron, acclimatised to a range of environmental salinities, BMC Ecol. 10 (2010) 1-8.

[46] U. Andersson, K. Tracey, HMGB1 Is a therapeutic target for sterile Inflammation and Infection, Annu. Rev. Immunol. 29 (2011) 139-162.

[47] B. Lu, C. Wang, M. Wang, W. Li, F. Chen, K.J. Tracey, H. Wang, Molecular mechanism and therapeutic modulation of high mobility group box 1 release and action: an updated review, Expert Rev. Clin. Immunol. 10 (2014) $713-727$. 